\title{
Pelatihan Penggunaan Aplikasi Google Classroom Sebagai Upaya Peningkatan Pembelajaran Online Bagi Guru Matapelajaran IPS
}

\author{
Bayu Kurniawan ${ }^{1 *}$, Agus Purnomo ${ }^{2}$, Idris ${ }^{3}$ \\ 1,2,3 Program Studi Pendidikan IPS FIS Universitas Negeri Malang
}

\section{A R T I C L E I N F O}

Article history:

Received 10 December 2019

Received in revised form

01 January 2020

Accepted 30 January 2020

Available online 28

February 2020

\section{Kata Kunci:}

Pelatihan, Google

Classroom, Pembelajaran

Online, Guru IPS

Keywords:

Training, Google

Classroom, Online

Learning, Social Studies

teachers

\begin{abstract}
A B S T R A K
Perkembangan teknologi telah membawa perubahan paradigma pembelajaran yang berbasis kelas menjadi online. Guru juga dituntut untuk merespon situasi ini sebagai peningkatan kompetensi mereka. Upaya-upaya yang dapat membantu guru dalam meningkatkan kompetensi mereka dalam pembelajaran online bisa dilakukan melalui proses pelatihan dan pendampingan. Makalah ini bertujuan untuk memaparkan hasil dari pelatihan penggunaan Google Classroom kepada guru matapelajaran IPS di MTs Kota Malang. Hasilnya menunjukkan bahwa: 1) hanya 7\% guru IPS yang menerapkan pembelajaran online, 2) penggunaan modul pelatihan sangat penting dan membantu peserta memahami materi pelatihan, 3) pelaksanaan pelatihan berjalan dengan baik dan guru sangat antusias, dan 4) ada permintaan tindaklanjut dari kegiatan pelatihan.
\end{abstract}

\section{A B S T R A C T}

Advances in Technological have brought a classroom-based learning paradigm to online. Teachers are required to respond to this situation so that they have better competence. Ways that can be done to achieve this goal are through training and accompaniment. This paper aims to explain the results of training in the use of Google Classroom to social studies teachers at MTs Malang. The results show that: 1 ) only $7 \%$ of social studies teachers apply online learning, 2) the use of training modules is very important and helps participants understand the training material, 3) the training runs well and the teacher is very enthusiastic, and 4) there are requests for follow-up from the activities training

\footnotetext{
* Corresponding author.

E-mail addresses: bayukurniawan123@gmail.com (Bayu Kurniawan)
} 


\section{Pendahuluan}

Di Era Revolusi Industri 4.0 dunia pendidikan semakin mengarahkan orientasinya pada teknologi. Kampanye-kampanye inovasi dalam pendidikan yang berbasis ICT selalu digalakan dalam bentuk bentuk penggunaan media dalam pendidikan (Kurniawan et al, 2019; Maskur et al, 2017; Nurryna, 2008; Pramono \& Setiawan, 2019; Rohmah et al, 2019). Sekali lagi kemajuan teknologi telah merubah segalagalanya, termasuk dibidang pendidikan. Kaitanya dengan proses pembelajaran saat ini, kemajuan teknologi sangat berpengaruh pada praktik pembelajaran di kelas. Bahkan dengan kemajuan teknologi, masalah jarak dan waktu dalam pembelajaran bisa di atasi, misalnya dengan pembelajaran daring menggunakan e-learning (Astuti \& Febrian, 2019; Bali, 2019; Darmayanti et al, 2007; Ibrahim, 2019; Munawaroh, 2005). Kondisi ini mungkin menjadi deklarasi bahwa pembelajaran tradisional sudah harus diperbaharui karena sudah usang.

Berbicara tentang pembelajaran daring yang memanfaatkan e-learning, di Indonesia ternyata sudah banyak berkembang pesat terutama di perguruan tinggi (Adawi, 2016; Sayekti, 2015). Pembelajaran daring ini juga diterapkan pada program Pendidikan Profesi Guru (PPG) saat ini. Hebatnya lagi, perkembangan pembelajaran berbasis teknologi saat ini sudah sampai pada penggunaan Massive Open Online Course (MOOC) di berbagai perguruan tinggi ternama dunia (Breslow et al., 2013; McAuley et al, 2010; Pappano, 2012; Sulistyo et al, 2019). Menggunakan MOOC akan membuat siapa saja bisa belajar atau menjadi mahasiswa di perguruan tinggi di dunia, bertemu dengan pengajar-pengajar kelas dunia dan lain sebagainya. Ini berarti pembelajaran sudah melepaskan semua batasan-batasan yang menghadang selama berabad-abad, baik itu jarak, waktu, ruang kelas dan hal-hal yang berbau administrasi (Cole, 2000).

Melihat situasi perkembangan pembelajaran saat ini sugguh sangat luar biasa. Lalu, bagimana dengan pembelajaran daring di Indonesia? Seperti yang telah disinggung di penjelasan sebelumnya, memang di Indonesia penerapan pembelajaran daring masih dimonopoli pada tingkat perguruan tinggi (Sumarno, 2019). Tidak banyak sekolah-sekolah menengah yang menerapkan pembelajaran daring. Alasan-alasan yang menghadang saat ini adalah kesiapan infrastruktur dan kultur di sekolah-sekolah (Borotis \& Poulymenakou, 2004). Tentunya ini akan menghambat para guru untuk menerapkan pembelajaran daring. Hanya sekolah-sekolah yang memiliki infrastruktur memadai saja mampu menerapkannya.

Meskipun demikian, setiap permasalahan pasti ada jalan keluarnya. Sejalan dengan perkembangan teknologi, maka peran perusahaan besar seperti Google sekan-akan memberikan kemudahan dalam segala bidang kehidupan. Termasuk dibidang pembelajaran, Google telah memfasilitasi para guru sebuah fitur yang bernama Google Classroom (Azhar \& Iqbal, 2018). Aplikasi ini akan membantu guru dalam menerapkan pembelajaran onlinenya. Aplikasi ini sangat mudah dioperasikan dan murah. Aplikasi ini menjadi solusi bagi guru untuk menerapkan pembelajaran online yang selama ini terhalang oleh biaya dan peralatan mahal.

Sungguh disayangkan, dengan adanya kemudahan seperti yang dijelaskan di atas, realitanya masih sedikit guru yang menggunakan aplikasi ini. Alasan terbesar dalam situasi ini adalah adanya kesenjangan digital di kalangan guru atau sering dikenal dengan gagap teknologi (Gaptek) (Muhammad Zulham, 2013). Solusi yang bisa dilakukan adalah dengan melakukan berbagai pelatihan (Wiradimadja et al, 2019) Berdasarkan permasalahan tersebut, maka penulis tertarik untuk melakukan kegiatan pengabdian kepada masyarakat dengan judul "Pelatihan Penggunaan Aplikasi Google Clasroom Sebagai Upaya Peningkatan Pembelajaran Online Bagi Guru Matapelajaran IPS MTs Di Kota Malang".

\section{Metode}

Pelaksanaan kegiatan pengabdian kepada masyarakat ini berbentuk pelatihan penggunaan aplikasi Google Classroom. Kegiatan pelatihan dilaksanakan bekerjasama dengan MGMP IPS MTs Kota Malang dan pengawas sekolah. Jumlah peserta dalam kegiatan pelatihan ini adalah 38 orang guru matapelajaran IPS yang mewakili 21 MTs. Ada beberapa tahapan utama yang dilakukan dalam kegiatan pelatihan ini, yakni: 1) perencanaan, 2) pelaksanaan, dan 3) evaluasi. Tahap perencanaan dimulai melalui proses identifikasi kelemahan peserta terhadap penggunan Google Classroom. Tahap perencanaan dilanjutkan dengan penyususnan modul pelatihan yang akan membantu peserta dalam memahami pembuatan akun dan pengoperasian Google Classroom secara mandiri. Penyusunan instrumen evaluasi juga termasuk dalam tahap perencanaan. Instrumen evaluasi menggunakan Google form dan bertujuan untuk mendapatkan data terkait pelaksanaan pelatihan.

Tahap pelaksanaan berisikan kegiatan berupa penyampaian materi, praktik penggunaan Google Classroom oleh peserta dan evaluasi kegiatan pelatihan. Kegiatan penyampaian materi dilanjutkan dengan 
sesi tanya jawab antara pemateri dan peserta, serta praktik yang dilakkan oleh peserta. Pada proses praktik, peserta didampingi dan dipandu oleh pemateri dan tim pelatihan. Tahap akhir dari proses pelatihan adalah evaluasi hasil kegiatan. Instrumen yang sudah disusun pada Google Classroom kemudian diberikan kepada peserta pelatihan untuk diisi. Data hasil dari Google Classroom dianalisis menggunakan SWOT. Upaya untuk memperkaya data hasil pengabdian dilakukan dengan kegiatan wawancara kepada beberapa peserta pelatihan.

\section{Hasil dan pembahasan}

1. Perencanaan: Identifikasi Pengetahuan Guru Terhadap Penggunaan Google Classroom

Pengetahuan guru IPS di tingkat MTs Kota Malang mengenai Google Classroom masih tergolong rendah. Hanya 7\% yang sudah pernah menggunakannya dalam pembelajaran (Gambar 1). Data terebut tentunya sangat memprihatikan di Era Revolusi Industri 4.0.

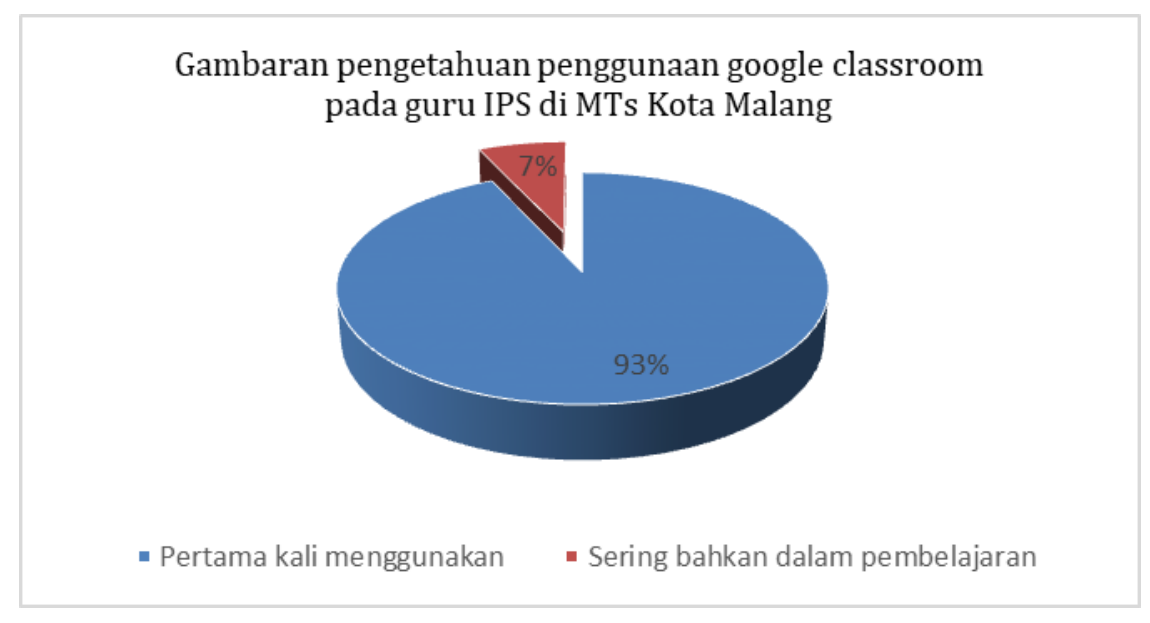

Gambar 1. Persentase pengetahuan guru menggunakan Google Classroom dalam pembelajaran Sumber: Data pribadi, 2019

Berdasarkan hasil identifikasi, ternyata kondisi tersebut merupakan dampak dari keterbatasan sarana dan prasarana teknologi di lingkungan sekolah masing-masing. Selain itu, Hasil wawancara juga menunjukkan bahwa pihak sekolah membatasi penggunaan telepon pintar dengan alasan mengganggu konsentrasi belajar. Guru berasumsi bahwa penggunaannya dalam pembelajaran akan membuat siswa terbiasa untuk mencari jawaban secara instan. Menurut sebagian guru, dampak dari terbiasanya siswa dalam mencari jawaban secara instan adalah siswa akan kesulitan untuk mengerjakan soal ujian jika terbiasa mencari jawaban di internet.

Keterbatasan sarana dan prasaran teknologi dilingkungan sekolah memang menjadi masalah yang cukup serius. Padahal, Peraturan Pemerintah Republik Indonesia Nomor 19 Tahun 2005 Tentang Standar Nasional Pendidikan pada Bab VII tentang Saran dan Prasarana (Republik Indonesia, 2005) sudah mengatur dengan jelas terkait fasilitas yang harus dimiliki oleh sekolah. Pada kenyataanya, pada tingkat SD hanya sebesar 27, 40\% jumlah ruang kelas yang dalam kondisi baik, di tingkat SMP sebesar 31, 28\% dan ditingkat SMA sebesar 45,95\% (Kemendikbud, 2018). Pembelajaran yang berbasis IT tentu membutuhkan ruang kelas yang baik dan memiliki sarana dan prasarana yang memadai, misalnya aliran listrik dan koneksi internet. Namun, ternyata masih ada sekitar 2.510 desa di Indonesia yang belum dialiri oleh listrik (PLN, 2018). Selain itu, sekitar 93.000 sekolah yang belum terhubung dengan internet (Liputan6.com, 2019). Fakta-fakta ini tentu perlu menjadi renungan bagi pemangku kekuasaan khususnya dibidang pendidikan. Pasalnya, kualitas dari suatu sekolah itu juga dipengaruhi oleh tercukupkanya unsur sarana dan prasarana yang dikelola dengan baik (Asiyai, 2012; Boeskens et al, 2018). Oleh karena itu, upaya-upaya peningkatan sarana dan prasarana harus diupayakan dengan baik

\section{Perencanaan: Penyediaan Modul Pelatihan}

Berbagai upaya dalam tercapainya suatu kegiatan pelatihan tentu perlu dipersiapkan secara baik. Salah satunya adalah modul pelatihan yang akan membantu peserta pelatihan untuk belajar mandiri. Oleh karena itu, dalam pelatihan ini juga disusun suatu modul pelatihan yang berisikan 34 halaman (Gambar 2). Selain itu, isi dari modul pelatihan ini adalah: 1) petunjuk penggunaan modul, 2) tujuan dan sasaran 
pelatihan, 3) kompetensi yang harus dicapai oleh peserta latiha, 4) pengenalan dasar terkait Google Classroom, dan 5) langkah-langkah dalam penggunaan Google Classroom yang dilengkapi dengan gambar petunjuk.

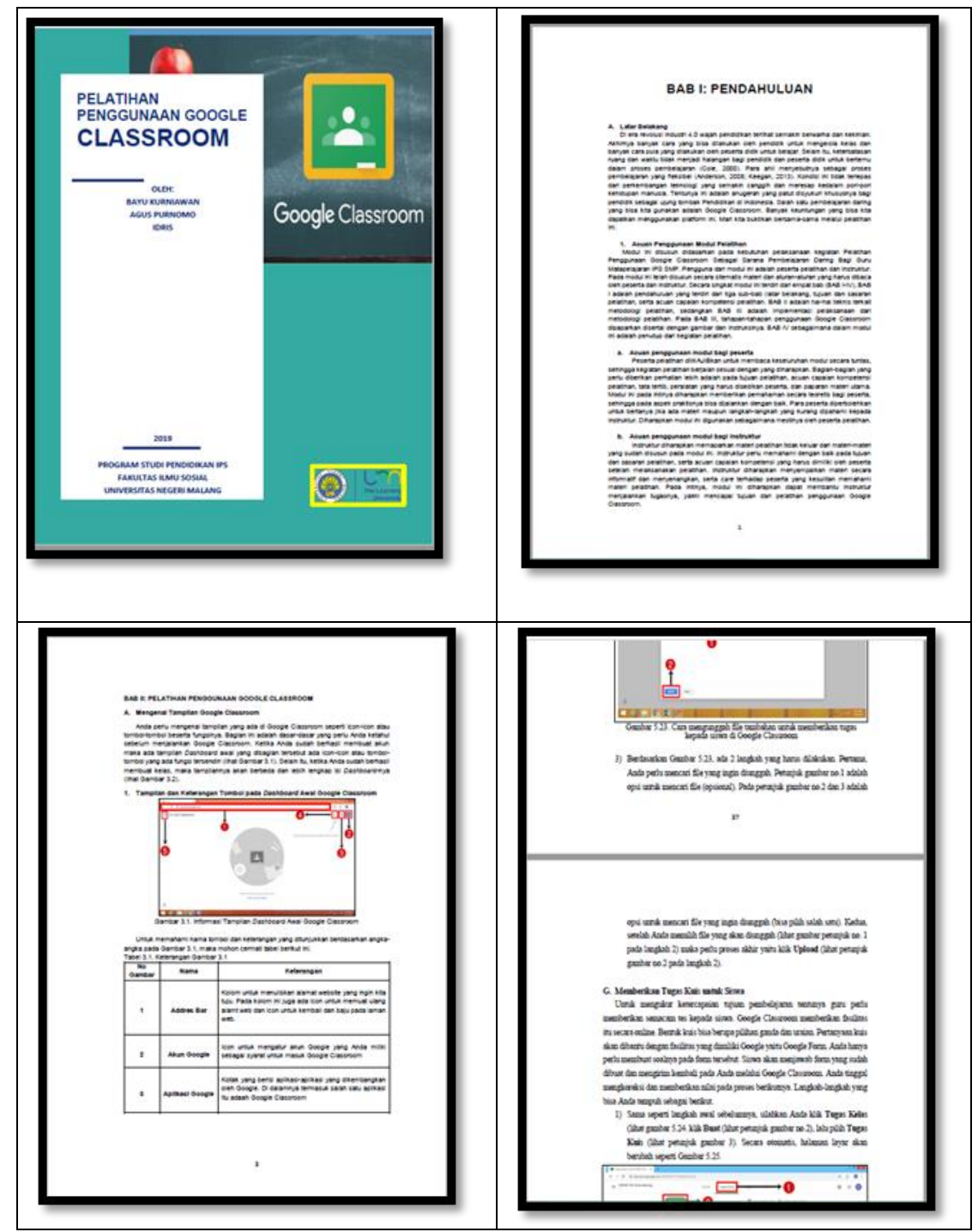

Sumber: Data pribadi, 2019

Gambar 2. Beberapa gambar potongan dari Modul Pelatihan

Modul pelatihan yang disediakan berupa cetak dan non-cetak. Modul yang berbentuk cetak diserahkan kepada peserta bersamaan dengan seminar kit, sedangkan non-cetak diberikan link Google Drive. Adapun link Google Drive dari Modul pelatihan adalah sebagai berikut: https://drive.google.com/file/d/1oCG6MSXVP1ZHiVyN3HHZoz3FgmiNeuMk/view?usp=sharing.

Penyusunan modul pelatihan akan membantu instruktur atau pemateri dalam menyampaikan materi pelatihan (Sumini, 2018). Modul pelatihan yang disusun bisa membantu peserta untuk belajar mandiri jika dibutuhkan diluar waktu pelatihan

\section{Pelaksanaan Pelatihan Penggunaan Aplikasi Google Classroom}

Pelatihan penggunaan aplikasi Google Classroom pada guru-guru matapelajaran IPS MTs di laksanakan pada hari Kamis, 10 Oktober 2019 di Gedung I1 ruang 206 Fakultas Ilmu Sosial Universitas Negeri Malang. Jumlah guru yang mengikuti pelatihan adalah 38 orang yang berasal dari berbagai MTs di Kota Malang. Proses pelatihan diawali dengan berbagai kegiatan opening, lalu dilanjutkan penyampaian materi, praktik oleh guru, dan evaluasi. 

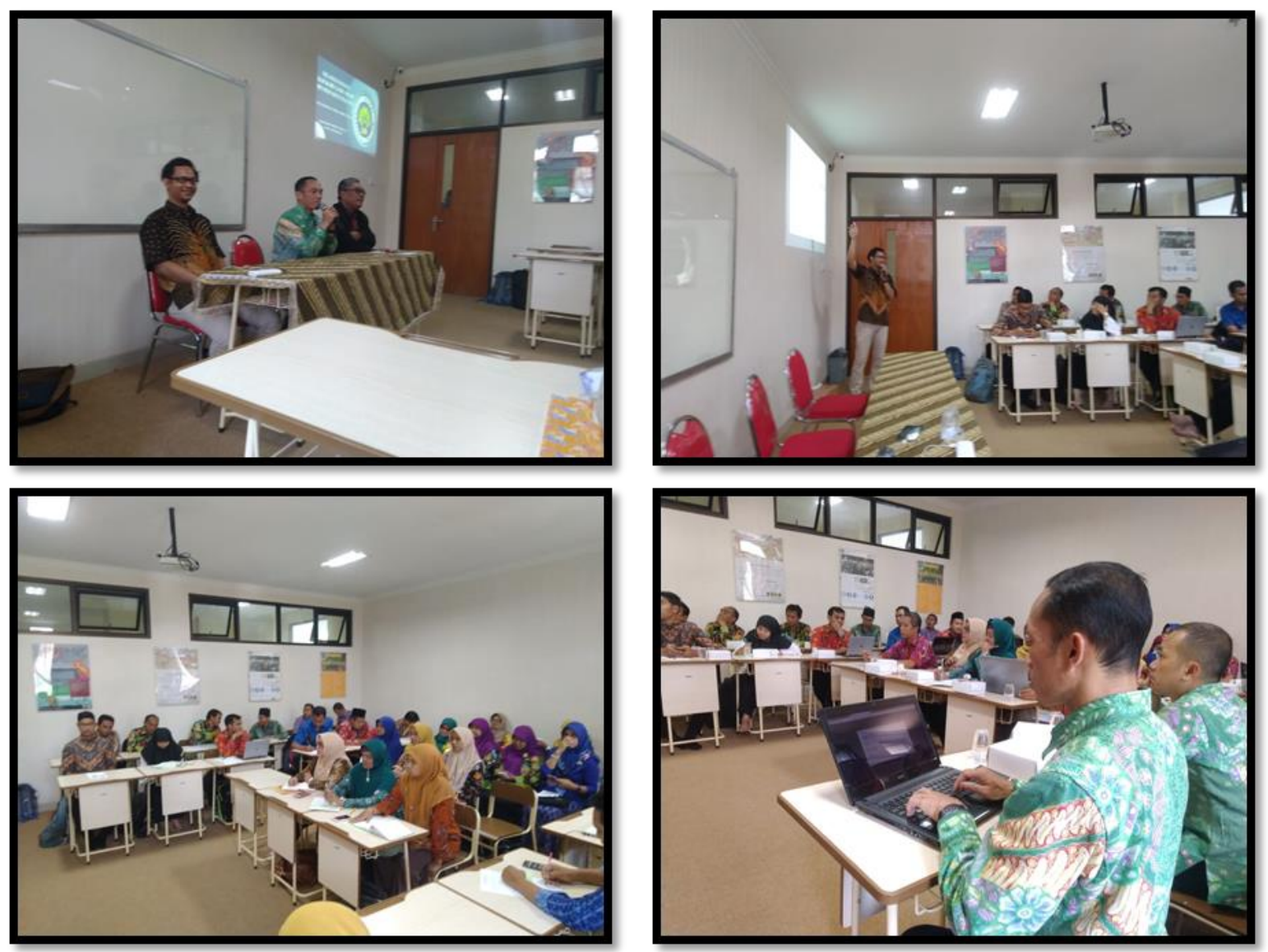

Gambar 3. Pelaksanaan Pelatihan Penggunaan Aplikasi Google Classroom Sumber: Data pribadi, 2019

Penyampaian materi dilakukan secara sistematis yang diawali dengan pengenalan Google Classroom kepada peserta pelatihan. Pemateri menjelaskan pentingnya pembelajaran online dalam dunia pendidikan saat ini sehingga guru perlu menerapkannya di sekolah. Salah satu platform yang bisa diterapkan adalah Google Classroom. Alasan pemilihan Google Classroom karena platform ini lebih mudah untuk digunakan oleh guru dan juga murah. Setelah itu, pemateri memulai menunjukkan cara membuat akun Google Classroom, mengundang siswa ke dalam kelas online, mengisi bahan ajar dan media pembelajaran serta instrumen penilaian dalam Google Classroom.

Pada proses penyampaian materi terkait Google Classroom, peserta pelatihan terlihat sangat antusias. Hal ini dibuktikan dengan banyaknya peserta yang bertanya kepada pemateri terkait langkahlangkah pembuatan akun Google Classroom. Ini tentu merupakan respon yang mengindikasikan antusiasme peserta.

\section{Evaluasi Kegiatan Pelatihan Penggunaan Aplikasi Google Classroom}

Setelah dikenalkan dengan pembelajaran daring dalam bentuk Google Classroom, pemikiran untuk menjadikan gawai sebagai sumber belajar mulai terbuka. Umpan balik yang mereka berikan seperti, minta pendampingan dalam pengelolaan kelas, paparan yang diberikan menambahkan wawasan tentang pola pembelajaran abad 21, dan permintaan untuk meng-kombinasikan dengan media lainnya. Umpan balik tersebut menandakan keterbukaan pikiran guru untuk menggunakan gawai (telepon pintar) sebagai bagian dari pembelajaran di kelas.

Pelatihan dalam bentuk pemberian materi berupa bahan bacaan dan penyampaian berbentuk praktik langsung mempermudah pemahaman guru. Hal tersebut dikuatkan dari hasil angket umpan balik keterlaksanaan pengabdian. Poin yang dievaluasi mencakup; (1) kualitas instruktur dalam menyampaikan materi, (2) ketersediaan fasilitas pendukung yang ada, dan (3) kejelasan modul pendukung kegiatan pendampingan. Rekap angket (Gambar 4) menunjukkan bahwa pelaksanaan pengabdian berjalan dengan baik karena didukung oleh instruktur yang baik dan dukungan fasilitas yang sesuai kebutuhan. 

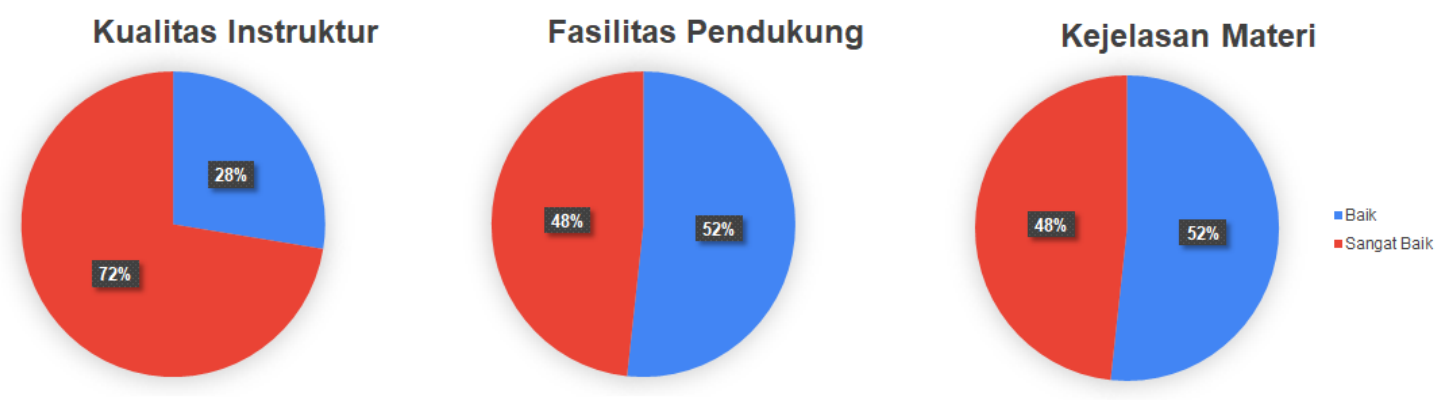

Sumber: Data pribadi, 2019

Gambar 4. Rekap angket pelaksanaan pelatihan penggunaan aplikasi Google Classroom

Hasil dari data yang dikumpulkan kemudian dianalisis menggunakan analisis Internal Faktor Evaluasi (IFE) dan Eksternal Faktor Evaluasi (EFE). Tujuannya adalah untuk menjabarkan tindak lanjut yang sesuai dengan kebutuhan mitra. Komponen dari masing-masing faktor (Error! Reference source not found.) dikumpulkan dengan teknik wawancara mendalam dengan beberapa guru.

Tabel 1. Hasil analisis Internal Faktor Evaluasi (IFE) dan Eksternal Faktor Evaluasi (EFE).

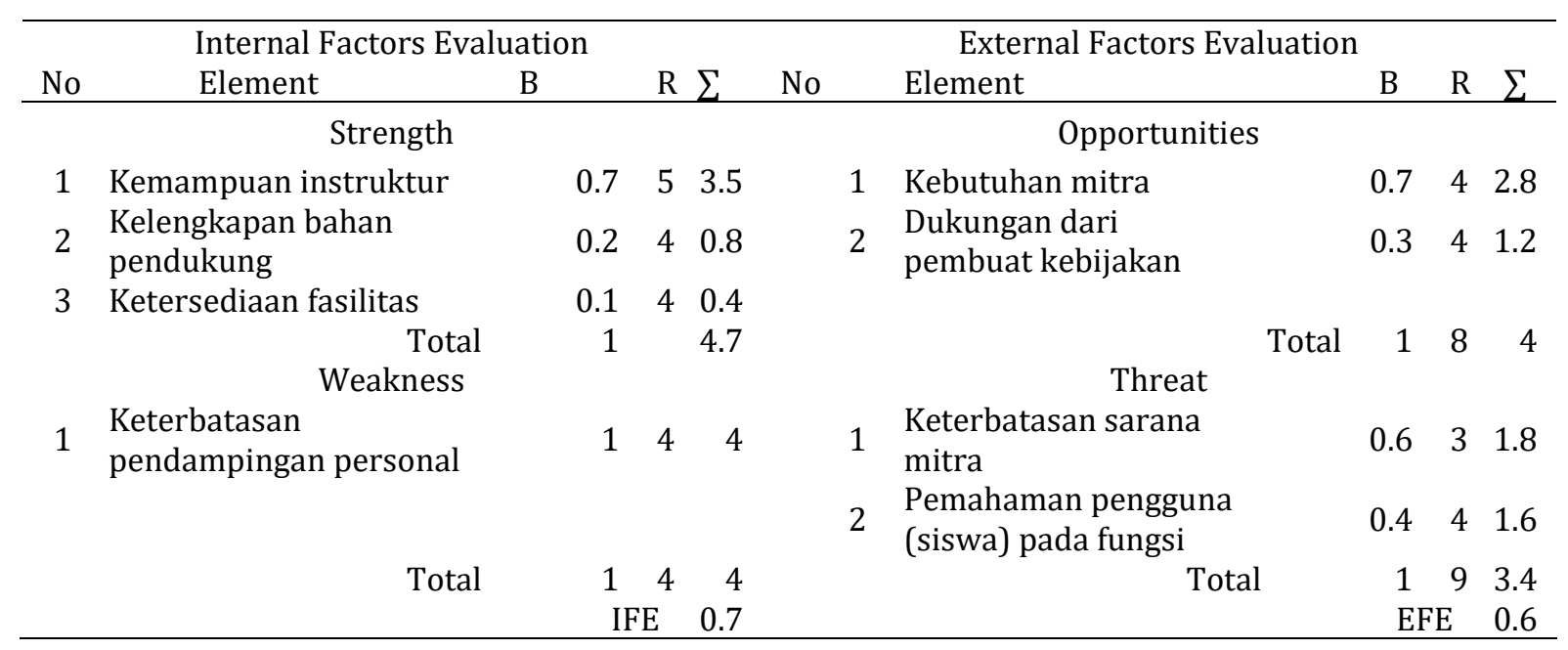

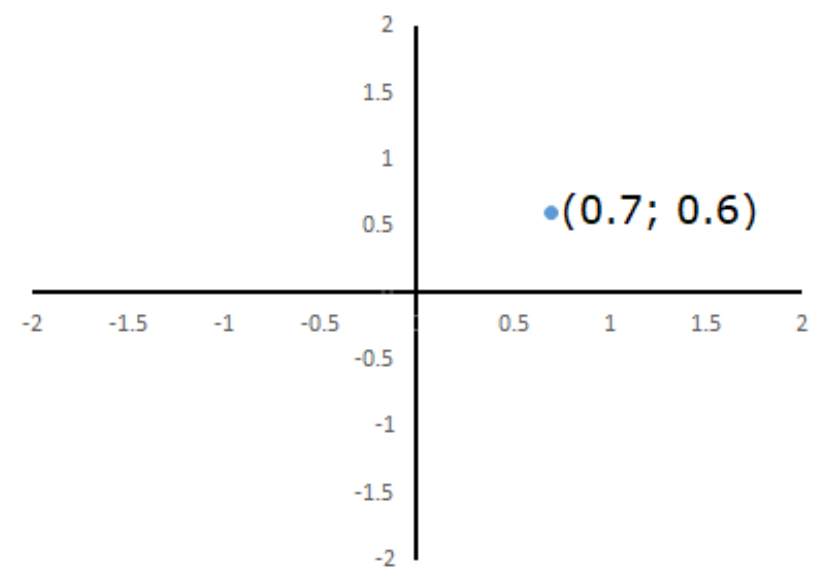

Gambar 5. Diagram IFE dan EFE

Pengujian dari IFE dan EFE menunjukkan nilai positif pada kedua sisi (5). Maka dapat disimpulkan bahwa kegiatan pengabdian dan permintaan tindak lanjut berada pada kuadran I. artinya kegiatan yang ada memiliki keunggulan dari aspek internal dan eksternal sehingga hanya perlu melakukan tindak lanjut sesuai rencana/permintaan. 


\section{Simpulan dan saran}

Berdasarkan hasil dari kegiatan pengabdian kepada masyarakat yang berupa pelatihan, maka dapat diketahui bahwa dari 38 orang guru matapelajaran IPS di MTs Kota Malang hanya 7\% saja yang pernah menerapkan pembelajaran online. Situasi ini dikarenakan minimnya sarana dan prasarana yang berupa teknologi di sekolah masing-masing. Selain itu, banyak sekolah yang melarang siswanya untuk membawa handphone dengan alas an dapat mengganggu konsentrasi belajar dan ketergantungan kepada jawaban di internet. Setiap pelatihan tentu membutuhkan modup pelatihan yang akan membantu dan membantu peserta dalam mencapai tujuan pelatihan, yakni penerapan Google Classroom sebagai platform pembelajaran online.

Pelaksanaan pelatihan berjalan dengan baik dan peserta antusias dalam proses penyampaian materi serta praktik. Hasil evaluasi kegiatan menunjukkan bahwa guru memiliki pemikiran yang terbuka terhadap pembelajaran online terutama penggunaan Google Classroom. Selain itu, berdasaran hasil timbal balik dari peserta, pelaksanaan pelatihan berjalan dengan baik. Hal ini ditunjukkan dengan penilaian instruktur yang mencapai $72 \%$ sangat baik, fasilitas pendukung $52 \%$ baik, dan kejelasan materi $52 \%$ baik, serta perlu ada tindak lanjut kegiatan pelatihan..

Berbagai saran yang perlu dilakukan oleh pengabdian lainnya yakni: 1) pelatihan penggunaan pembelajaran online menggunakan platform yang bervariasi perlu ditingkatkan, 2) bukan hanya pembelajaran online saja, namun media-media pembelajaran yang inovatif perlu dilakukan pelatihan dan pendampingan guna meningkatkan kompetensi guru-guru, 3) kualitas pelatihan dan pendampingan perlu tingkatkan lagi bagi dari segi fasilitas maupun metodenya

\section{Daftar Rujukan}

Adawi, R. (2016). Pembelajaran Berbasis E-Learning. eprint. Retrieved from http://digilib.unimed.ac.id/541/

Asiyai, R. I. (2012). Assessing school facilities in public secondary schools in Delta State, Nigeria. African Research Review, 6(2), 192-205.

Astuti, P., \& Febrian, F. (2019). Blended learning: Studi efektivitas pengembangan konten e-learning di perguruan tinggi. Jurnal Tatsqif, 17(1), 104-119.

Azhar, K. A., \& Iqbal, N. (2018). Effectiveness of Google classroom: Teachers' perceptions. Prizren Social Science Journal, 2(2), 52-66.

Bali, M. M. E. I. (2019). Implementasi Media Pembelajaran Berbasis Teknologi Informasi dan Komunikasi dalam Distance Learning. Tarbiyatuna: Kajian Pendidikan Islam, 3(1), 28-38.

Boeskens, L., Liebowitz, D., Lima, G., \& Radinger, T. (2018). Responsive School Systems: Connecting Facilities, Sectors and Programmes for Student Success. OECD Reviews of School Resources. OECD Publishing.

Borotis, S., \& Poulymenakou, A. (2004). E-Learning Readiness Components: Key Issues to Consider Before Adopting e-Learning Interventions. 1622-1629. Retrieved from https://www.learntechlib.org/primary/p/11555/

Breslow, L., Pritchard, D. E., DeBoer, J., Stump, G. S., Ho, A. D., \& Seaton, D. T. (2013). Studying Learning in the Worldwide Classroom Research into edX's First MOOC. Research \& Practice in Assessment, 8, 1325.

Cole, R. A. (2000). Issues in Web-based Pedagogy: A Critical Primer. Greenwood Publishing Group.

Darmayanti, T., Setiani, M. Y., \& Oetojo, B. (2007). E-Learning Pada Pendidikan Jarak Jauh: Konsep Yang Mengubah Metode Pembelajaran Di Perguruan Tinggi Di Indonesia. Jurnal Pendidikan Terbuka Dan Jarak Jauh, 8(2), 99-113.

Ibrahim, N. (2019). ICT Untuk Pendidikan Terbuka Jarak Jauh. Jurnal Teknodik, 005-018. 
Kemendikbud. (2018). Indonesia Education Statistics In Brief 2018/2019. Retrieved from http://publikasi.data.kemdikbud.go.id/uploadDir/isi_03351F6F-A355-4531-9DC1109E5E4C6C17_.pdf

Kurniawan, B., Idris, I., Purnomo, A., Wiradimadja, A., \& Sukamto, S. (2019). Using Broadcasting Learning Design to Enhance Student's Experiential Skill. International Journal of Emerging Technologies in Learning (IJET), 14(16), 172-180.

Liputan6.com. (2019, March 28). Menkominfo: 214 Ribu Sekolah di Indonesia Harus Terhubung ke Internet. Retrieved November 25, 2019, from Liputan6.com website: https://www.liputan6.com/tekno/read/3928278/menkominfo-214-ribu-sekolah-di-indonesiaharus-terhubung-ke-internet

Maskur, R., Nofrizal, N., \& Syazali, M. (2017). Pengembangan Media Pembelajaran Matematika dengan Macromedia Flash. Al-Jabar: Jurnal Pendidikan Matematika, 8(2), 177-186. https://doi.org/10.24042/ajpm.v8i2.2014

McAuley, A., Stewart, B., Siemens, G., \& Cormier, D. (2010). The MOOC Model for Digital Practice. University of Prince Edward Island, 64.

Muhammad Zulham, 071016074. (2013). Kesenjangan Digital di Kalangan Guru SMP (Studi Deskriptif Mengenai Kesenjangan Aksesibilitas dan Kapabilitas Teknologi Informasi di Kalangan Guru SMP Kecamatan Krian) (Skripsi, UNIVERSITAS AIRLANGGA). Retrieved from http://lib.unair.ac.id

Munawaroh, I. (2005). Virtual Learning dalam Pembelajaran Jarak Jauh. Majalah Ilmiah Pembelajaran, (2). Retrieved from https://www.neliti.com/publications/220000/virtual-learning-dalampembelajaran-jarak-jauh

Nurryna, A. F. (2008). Pengembangan Media Pendidikan Untuk Inovasi Pembelajaran. Speed - Sentra Penelitian Engineering Dan Edukasi, 1(2). https://doi.org/10.3112/speed.v1i2.1354

Pappano, L. (2012, November 2). Massive Open Online Courses Are Multiplying at a Rapid Pace. The New York Times. Retrieved from https://www.nytimes.com/2012/11/04/education/edlife/massiveopen-online-courses-are-multiplying-at-a-rapid-pace.html

PLN. (2018). RUPTL: Rencana Usaha Penyediaan Tenaga Listrik PT. PLN (PERSERO) 2018-2027. Retrieved from https://www.pln.co.id/statics/uploads/2018/04/RUPTL-PLN-2018-2027.pdf

Pramono, A., \& Setiawan, M. D. (2019). Pemanfaatan Augmented Reality Sebagai Media Pembelajaran Pengenalan Buah-Buahan. INTENSIF: Jurnal Ilmiah Penelitian Dan Penerapan Teknologi Sistem Informasi, 3(1), 54-68.

Republik Indonesia. Peraturan Pemerintah Republik Indonesia Nomor 19 Tahun 2005 Tentang Standar Nasional Pendidikan. , (2005).

Rohmah, R. N., Sari, W. A. M. P., Pangasta, D. G. D., \& Deddiliawan, A. (2019). Pengembangan Mantri Caino: Inovasi Media Pembelajaran Interaktif Berbasis Etnomatematika. Jurnal Riset Teknologi Dan Inovasi Pendidikan (JARTIKA), 103-116.

Sayekti, R. (2015, December 28). Implementasi E-learning di Perguruan Tinggi: Menjawab Tantangan Teknologi dan Perkembangan Pendidikan [Monograph]. Retrieved October 10, 2019, from http://repository.uinsu.ac.id/1916/

Sulistyo, W. D., Nafi'ah, U., \& Idris, I. (2019). The Development of E-PAS Based on Massive Open Online Courses (MOOC) on Local History Materials. International Journal of Emerging Technologies in Learning (IJET), 14(09), 119-129.

Sumarno, A. (2019). Spada Indonesia. Retrieved October 10, 2019, from Spada Indonesia website: http://spada.ristekdikti.go.id// 
Sumini, S. (2018). Pengembangan Modul Pelatihan Untuk Meningkatkan Kualitas Hasil Pelatihan Di Balai Latihan Kerja. Prosiding Seminar Nasional, 1. Retrieved from http://www.jurnal.ustjogja.ac.id/index.php/semnasmpd/article/view/3025

Wiradimadja, A., Kurniawan, B., \& Sukamto, S. (2019). Pelatihan PTK Bagi Guru IPS SMP/MTs Malang Raya. Jurnal Praksis Dan Dedikasi Sosial, 0(0), 6-12. 